УДК [001.8:004.77]:37.011.3

Коломісць Алла Миколаївна

доктор педагогічних наук, професор, проректор з наукової роботи

Вінницький державний педагогічний університет імені Михайла Коцюбинського, м. Вінниця, Україна ORCID ID 0000-0003-0536-0147

alla_kolomiec@mail.ru

Громов Свген Володимирович

кандидат педагогічних наук, начальник аналітично-організаційного відділу

Вінницький державний педагогічний університет імені Михайла Коцюбинського, м. Вінниця, Україна

ORCID ID 0000-0002-0234-606X

vdpu2004@i.ua

\title{
НЕТНОГРАФІЧНИЙ АНАЛІЗ ТЕМАТИЧНОГО СПЕКТРУ ПЕДАГОГІЧНИХ ДОСЛІДЖЕНЬ У ВИДАННЯХ $З$ НАУКОМЕТРИЧНОЇ БАЗИ SCOPUS
}

\begin{abstract}
Анотація. У статті здійснено нетнографічний аналіз сайтів закордонних педагогічних видань, що входять до наукометричної бази Scopus, оцінено пріоритетні напрями педагогічних досліджень у найбільш цитованих журналах світу. Проаналізовано тематичне покриття перших трьох сотень педагогічних видань 3 рейтингового списку, що представлений на Інтернет-платформі Scimago Journal \& Country Rank. Проведено порівняння показників цитованості закордонних педагогічних журналів 3 відповідними показниками видань технічного, природничого, правового та політичного спрямування. Авторами було спростовано розповсюджену помилкову думку про недостатню представленість або взагалі відсутність педагогічних видань у базі даних Scopus. 3'ясовано, що серед педагогічних видань, які індексуються у Scopus, найбільша кількість присвячена проблематиці загальної освіти і виховання; педагогічної психології і соціології; організації педагогічних досліджень і педагогічної статистики.
\end{abstract}

Ключові слова: нетнографічний аналіз; порівняння; педагогічні видання; тематика досліджень; наукометрична база Scopus; Інтернет-платформа Scimago Journal \& Country Rank; пріоритети педагогічної науки.

\section{1. ВСТУП}

Постановка проблеми. Наявність публікацій науковця в наукометричній базі Scopus $є$ обов'язковим показником його наукової активності й продуктивності [1], а цитованість у цій базі суттєво впливає на показники наукової установи чи вищого навчального закладу в різних рейтингових системах. Зокрема у Вебометричному рейтингу університетів світу (англ. Webometrics ranking of world's universities), який аналізує ступінь представлення діяльності університетів в Інтернет-просторі, звертають увагу на параметр EXCELLENCE (Висока якість). Цей параметр враховує наукові статті, що опубліковані працівниками університету в журналах, проіндексованих бібліометричною базою Scopus, i входять до складу 10\% статей, найбільш цитованих у своїх наукових галузях за версією Scimago Group.

Тому погоджуємось з українськими науковцями, які наголошують на актуальності інтеграції вітчизняної науки в європейський і світовий дослідницький і освітянський простори шляхом внесення i підтримки присутності наших публікацій у наукометричних міжнародних базах даних Scopus, Web of Science та ін. [2].

Можливості внесення вищих навчальних закладів України до наукометричної бази через індексацію наукових журналів у Scopus й опублікування вченими своїх праць у зареєстрованих у базі даних виданнях проаналізовані в статті [2, с. 6]. Авторами представлено процедуру індексації нових видань базою даних, розкрито 
критерії відбору видань й оцінювання якості наукової діяльності вчених і колективів за допомогою індексів цитованості, Гірша, імпакт-фактора.

Очевидно, що для педагогічних ВНЗ досягнення високих результатів за показником EXCELLENCE можливе лише за умови активного публікування і високої цитованості в провідних наукових виданнях світового рівня, зокрема й з педагогічного напряму. Тривалий час це здавалось неможливим, оскільки була поширеною думка, що педагогічних видань у Scopus немає. Пояснюємо це тим, що на платформі Scopus представлено лише 38 журналів з України, і жоден 3 них не належить до видань педагогічного напряму. Тому $\epsilon$ потреба здійснити аналіз сайтів закордонних педагогічних видань, які входять до бази Scopus, й оцінити пріоритетні напрями педагогічних досліджень у найбільш цитованих журналах світу.

Для визначення найактуальніших проблем педагогіки, що найбільше хвилюють світову наукову спільноту, нами було вирішено здійснити нетнографічний аналіз тематики публікацій наукових журналів, що визнані найавторитетнішими у світі серед 239 країн.

Аналіз останніх досліджень і публікацій. Нетнографія - один із зарубіжних педагогічних підходів до наукових досліджень Інтернет-мережі. Це поняття в науковий обіг увів американський учений у сфері досліджень в Інтернеті - Роберт В. Козинець (Robert V. Kozinets), утворивши його 3 двох англійських слів: «інтернет» («inter[net]») i «етнографія» («ethnography»). Нетнографія - це галузь етнографії, що вивчає поведінку людей у мережі й концентрується навколо культурологічних, символічних та інформаційних ідей [3]. Зазначимо, що в англомовних країнах етнографія належить не до історичних, а до суспільствознавчих наук. А тому аналогом етнографії виступає соціальна (в Англії) або культурна (у США) антропологія, котра має дещо інший, аніж наша етнографія, дослідницький об'єкт - людину, а не народ.

Об'єктами етнографії є сучасна людина, іiі діяльність, смаки, інтереси, потреби. До найпоширеніших методів нетнографічного дослідження науковці відносять вивчення окремих веб-сайтів, особливо популярних у досліджуваній цільовій групі. У процесі нетнографічних досліджень здійснюється науковий пошук, під час якого факти про предмет дослідження здобуваються шляхом вибіркового спостереження й теоретичної інтерпретації того, що бачимо; за допомогою запитань й інтерпретації відповідей; шляхом упорядкування нотаток і аудіо або відео записів; у процесі підготовки наукових звітів.

Нетнографія як метод для вивчення поведінки суб'єктів навчально-виховного процесу в Інтернет-мережі був застосований В. Биковим i М. Лещенко в статті «Цифрова гуманістична педагогіка відкритої освіти», де вказано, що методологія й методи досліджень класичної педагогіки, потребують перегляду й удосконалення в контексті сучасних реалій навчально-виховного процесу, потреб та інтересів усіх його суб'єктів [4, с. 19].

Алгоритм здійснення нетнографічного дослідження розкрито в статті української дослідниці М. Лещенко [5, с. 254].

Нетнографія серед зарубіжних науковців стала популярним методом збирання й аналізу якісної інформації на основі висловлювань споживачів в Інтернет-спільнотах. Це варіант етнографічних досліджень, у яких дослідник, будучи учасником Інтернетспільноти, використовує цей метод для спостереження за цією спільнотою для одержання необхідної інформації [3].

Оскільки Інтернет-спільнота педагогів-науковців $є$ своєрідною цільовою групою, яку цікавлять сучасні проблеми освіти й методи розв'язання цих проблем, а більшість сучасних наукових публікацій (висловлювань науковців), зокрема й педагогічного 
спрямування, представлені в мережі Інтернет, то вважаємо доцільним проаналізувати сайти найпопулярніших науково-педагогічних журналів.

3 огляду на те, що Scopus $є$ найбільшою у світі реферативною базою даних про наукові видання, то саме вона була нами використана для отримання релевантної наукової інформації та її оцінювання в найкоротший термін.

Невирішені аспекти проблеми. У світі науки за останні роки поняття нетнографія все частіше пов'язують 3 дослідженнями соціально-психологічних i когнітивних явищ в Інтернеті [6], [7], [3]. Проте цей метод дослідження лише починає застосовуватись науковою спільнотою України, про що свідчить вкрай рідкісне його згадування не лише в наукових публікаціях, а й у Інтернет-джерелах. За українським ключовим словом нетнографія в пошуковій системі Google знаходимо 122 документи, а за словосполученням нетнографічні методи - лише 7.

Нетнографічного аналізу тематики педагогічних досліджень, представлених у найбільшій наукометричній базі Scopus, дотепер здійснено ще не було. Ми знайшли лише перелік журналів з гуманітарних наук, що входять до бази Scopus, 3 коротким описом тематики питань, що в них аналізуються (на сайті Київського університету ім. Бориса Грінченка).

Метою статті $\epsilon$ нетнографічний аналіз тематичного спектру педагогічних досліджень, представлених у провідних науково-педагогічних виданнях світу, що входять до наукометричної бази Scopus, і визначення пріоритетних тем публікацій у журналах з високими індексами цитування.

\section{2. МЕТОДИ ДОСЛІДЖЕННЯ}

У статті було використано комплекс методів дослідження: аналіз рейтингових систем - для 3'ясування основних параметрів, що використовуються в рейтинговому оцінюванні університетів; нетнографія - для з'ясування тематики досліджень, яка найбільше цікавить світову науково-педагогічну спільноту; класифікації - для визначення основних напрямів педагогічних досліджень; порівняння - для визначення найбільш цитованих журналів і з'ясування місця педагогічних видань у рейтинговому списку наукових журналів Scimago Journal Rank (SJR).

Організовуючи нетнографічне дослідження, до найпоширеніших методів якого належить вивчення окремих веб-сайтів, ми скористались рекомендаціями М. Лещенко, яка пропонує здійснювати поступову реалізацію таких шести кроків: 1) планування; 2) вхід у мережу; 3) збір даних; 4) інтерпретація, 5) етична стандартизація; 6) презентація результатів [4, с. 254].

32000 року дослідницькою групою SCImago іспанського Університету Гранади на платформі Scimago Journal \& Country Rank щорічно публікується рейтинг журналів, що входять до наукометричної бази Scopus. За географічним охопленням Scopus $€$ універсальною базою даних, серед проіндексованих назв 47\% видаються у Західній Європі, 33\% - у Північній Америці, 9\% - видання Азійсько-Тихоокеанського регіону, 5\% назв східноєвропейських видавців (у т. ч. близько 300 російських, 39 білоруських і 38 українських назв журналів) та по 2\% видань 3 Австралії і Океанії, Африки i Південної Америки. Найбільше документів у цій базі мають Сполучені Штати Америки. Принагідно зазначимо, що 3239 країн за кількістю документів, представлених у базі Scopus, Україна станом на кінець 2016 року займала 40-е місце.

Перше місце в рейтингу журналів на початок 2017 року посів журнал із Великобританії Nature Reviews Molecular Cell Biology, який має показник інтенсивності цитованості 32, 928 та індекс Гірша $\mathrm{h}=324$. 
Як видно з цього рейтингу, з 29713 наукових журналів лише 1066 присвячені проблемам освіти, що становить близько 3,6\%. Перше місце в рейтингу педагогічних видань (хоч і не з найвищим індексом Гірша $\mathrm{h}=72$ ) займає журнал із США Journal of Engineering Education, у якого показник інтенсивності цитованості $\mathrm{SJR}=6,176$. Найбільший індекс цитувань $\mathrm{h}=189$ у журналу «Child Development», хоч він і займає 10-е місце в рейтингу з показником інтенсивності цитованості SJR $=3,116$.

Цей показник обчислюється складніше, ніж імпакт-фактор, з урахуванням не лише кількості цитувань, а й ступеня авторитетності журналів, у яких є посилання на даний журнал. Тобто, рейтинг наукових журналів у Scimago Journal Rank (SJR) базується на перенесенні престижності від одного журналу до іншого; згадана престижність переноситься через посилання, які один журнал робить на усі інші журнали, а також на самого себе. Остаточний розрахунок престижності журналу $є$ багатоетапним ітераційним процесом, у якому престижність журналу на етапі $i$ залежить від престижності кола журналів на етапі $i-1$. Він розраховується за такою формулою:

$$
S J R_{i}=\frac{(1-d-e)}{N}+e \frac{A r t_{i}}{\sum_{j=1}^{N} A r t_{j}}+d \cdot \sum_{j=1}^{N} \frac{C_{j i} \cdot S J R_{j}}{C_{j}} \cdot \frac{1-\left(\sum_{k s[D \text { angling-nodes }} S J R_{k}\right)}{\sum_{h=1}^{N} \sum_{k=1}^{N} \frac{C_{k h \cdot S J R_{k}}}{C_{k}}}+
$$

$$
\begin{gathered}
+d \cdot\left[\sum_{k r[D a n g l i n g-n o d \theta t]} S J R_{k}\right] \cdot \frac{A r t_{i}}{\sum_{j=1}^{N} A r t_{j}} \\
S J R Q_{i}=\frac{S J R_{i}}{A r t_{i}}
\end{gathered}
$$

де

$S J R i$ - SJR рейтинг журналу $i$;

$C j i$ - цитування з журналу $j$ на журнал $i$;

$C j$ - кількість посилань журналу $j$;

$d$ - константа, нормальне значення 0,85 ;

$e$ - константа, нормальне значення 0,10 ;

$N$ - кількість журналів;

$A r t j$ - кількість статей у журналі $j$.

\section{3. РЕЗУЛЬТАТИ ДОСЛІДЖЕННЯ}

Порівняння показників цитованості журналів показує, що педагогічні видання користуються значно меншою популярністю серед науковців, ніж журнали 3 природничих чи технічних наук, але в категорії соціальних наук інтенсивність їх цитування співрозмірна 3 журналами 3 правових i політичних наук. Нами було проаналізовано тематичне покриття перших трьох сотень педагогічних видань 3 рейтингового списку, а саме тих, які мають показник інтенсивності цитування SJR > 0,5. Загалом спектр розподілу тематики назв педагогічних журналів за галузями освіти має такий вигляд (табл.1). 
Таблиия 1

Розподіл назв педагогічних видань у базі Scopus за галузями освіти

\begin{tabular}{|c|l|c|}
\hline \multicolumn{1}{|c|}{ Го.лузь освітньої сфери } & \% \\
\hline 1 & \multicolumn{1}{|c|}{ Загальні проблеми освіти і виховання } & 17,2 \\
\hline 2 & Педагогічна психологія, соціологія & 11,3 \\
\hline 3 & Організація педагогічних досліджень, педагогічна статистика & 9,6 \\
\hline 4 & Лінгвістична освіта & 8,0 \\
\hline 5 & Управління й організація освіти & 7,6 \\
\hline 6 & Інформатизація освіти & 6,7 \\
\hline 7 & Інклюзивна освіта & 6,0 \\
\hline 8 & Медична освіта & 5,4 \\
\hline 9 & Природнича освіта & 4,9 \\
\hline 10 & Проблеми початкової і дошкільної освіти & 3,6 \\
\hline 11 & Проблеми вищої школи й освіти дорослих & 3,3 \\
\hline 12 & Педагогічна освіта & 3,0 \\
\hline 13 & Математична освіта & 2,3 \\
\hline 14 & Культурологічна і мистецька освіта & 2,3 \\
\hline 15 & Туристична освіта і фізичне виховання & 2,3 \\
\hline 16 & Порівняльна педагогіка & 2,0 \\
\hline 17 & Інженерна освіта & 1,6 \\
\hline 18 & Економічна освіта & 1,3 \\
\hline 19 & Екологічна освіта & 1,0 \\
\hline 20 & Правова освіта & 0,6 \\
\hline
\end{tabular}

У проаналізованому рейтинговому списку на останніх позиціях знаходяться блихько півтори сотні матеріалів конференцій загально-педагогічної тематики і тих, що присвячені вузьким питанням часткових методик, окремим питанням виховання тощо. Зрозуміло, що цитованість таких матеріалів досить низька, оскільки вони цікавлять вузьке коло науковців.

Інформацію про інтенсивність цитованості, індекс Гірша журналу та інші наукометричні відомості можна знайти на сайті кожного журналу за відповідним посиланням (Source). Основні показники цитованості й престижності різних журналів представляються у вигляді результуючого графіку, що представлений на рис. 1.

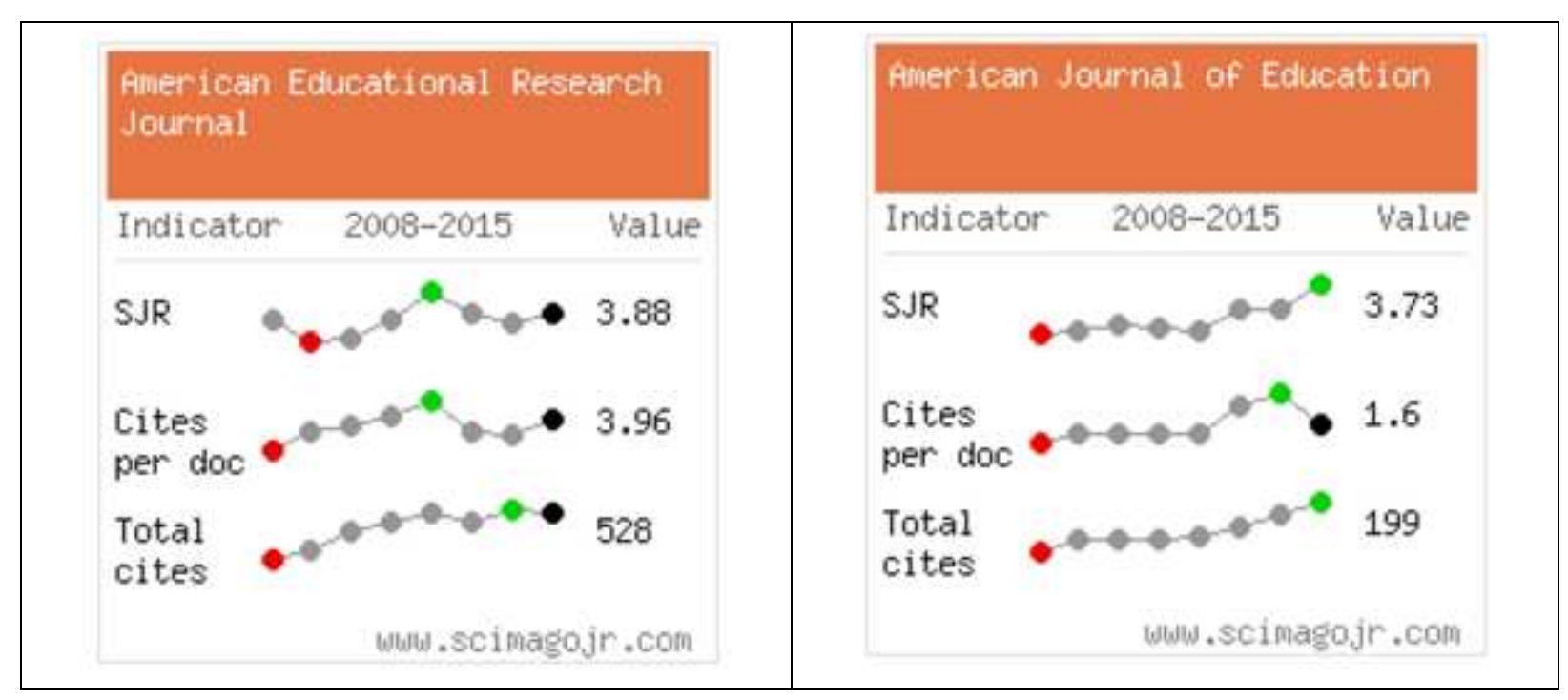




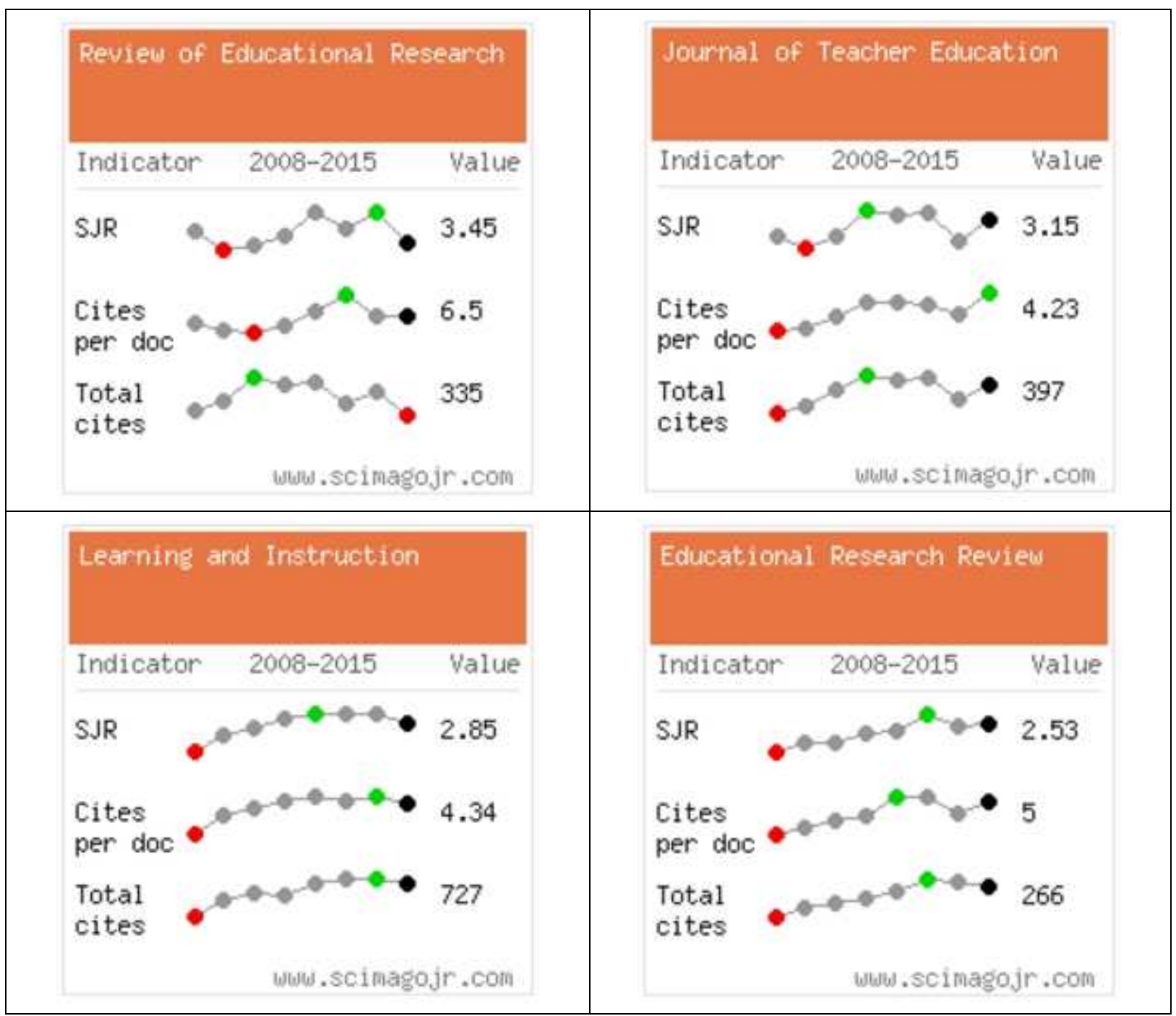

Рис. 1. Основні показники ичитованості й престижності журналу

На рисунку представлені графіки цитованості журналів загальної педагогічної спрямованості з першої «двадцятки» рейтингу Scimago Journal \& Country Rank. Bepхня крива Scimago Journal Rank Indicator (SJR) - відносний показник, що відображає фактор впливу i престижність журналу, тобто середню кількість зважених цитувань, отриманих у певному році документами, опублікованими в журналі упродовж попередніх трьох років. Середня крива Cites per Doc - відносний показник, що відображає середню кількість цитувань на один документ, опублікований у виданні, упродовж кількох років. Нижня крива Total Cites - абсолютний показник, що відображає загальну кількість цитувань опублікованих документів журналу в певному році. Червоним кольором помічений рік найменшого значення показника, зеленим - рік найбільшого значення показника, чорним - поточне значення показника.

3 огляду на те, що в перших кількох сотнях рейтингового списку виявилось найбільше видань, присвячених загальним проблемам освіти, то саме інтернет-сайти таких журналів було нами обрано для визначення їх тематичного покриття.

Найбільш широкою, як і слід було очікувати, виявилась тематика журналів, що знаходяться в перших двох десятках рейтингу. Для точнішої картини тематичного покриття найбільш рейтингових педагогічних видань із бази Scopus нижче ми пропонуємо короткий огляд їх наукових пріоритетів. 
Журнал «American Educational Research Journal» (Американський журнал освітніх досліджень) http://journals.sagepub.com/home/aer має за мету розповсюдження оригінальних емпіричних i теоретичних досліджень у галузі освіти. Редактори наголошують, що публікуються лише рецензовані статті 3 широкого розмаїття академічних дисциплін і практичних галузей; не приймаються рукописи, що $є$ есеями, оглядами, оцінками програм, а також короткими доповідями 3 досліджень питань вузької спрямованості; перевага надається дослідженням, що торкаються значущих політичних, культурних, соціальних, економічних та організаційних питань в освіті. Також заохочується публікація матеріалів, що висвітлюють питання освіти впродовж усього життя й усіх форм навчання, а також статті міждисциплінарної та багатодисциплінарної спрямованості.

Політика журналу American Journal of Education (Американський освітній журнал) http://www.journals.uchicago.edu/toc/aje/current спрямована на інтеграцію значного інтелектуального і методологічного розмаїття освітніх знань, заохочення жвавого діалогу між освітянами-теоретиками й освітянами-практиками. Для досягнення означеної мети журнал публікує матеріали, що презентують дослідження, теоретичні викладки, філософські аргументи, критичний синтез різних освітніх запитів, інтеграцію освітніх знань, освітньої політики і практики.

Журнал Internet and Higher Education (Інтернет i вища освіта) https://www.journals.elsevier.com/the-internet-and-higher-education/ щоквартально публікує рецензовані міждисциплінарні наукові статті, які відображають сучасні результати, а також перспективи розвитку он-лайн навчання, викладання й адміністрування освіти вищого рівня. Завданням журналу є наукова презентація й розповсюдження теоретичних і прикладних знань у галузі інноваційного розвитку Інтернет-технологій навчання й викладання, а також демонстрація позитивного впливу розвитку IT-технологій на наповнення змісту вищої освіти.

Журнал Review of Educational Research (Огляд освітніх досліджень) http://journals.sagepub.com/home/rer публікує статті, що містять критичні, інтегративні огляди наукової літератури в галузі освітніх досліджень. Такі огляди мають містити концептуалізації, інтерпретації, а також синтез літератури й наукових робіт широкого спектру освітніх досліджень. Журнал заохочує до підготовки матеріалів, у яких 3 освітянської точки зору висвітлюються результати наукових досліджень у галузі психології, соціології, історії, філософії, політичних наук, економіки, комп'ютерних наук, статистики, антропології, біології. Журнал не схвалює публікацію оригінальних емпіричних досліджень, якщо тільки вони не $\epsilon$ частиною більш широкого інтегративного огляду.

Журнал Journal of the Learning Sciences (Журнал 3 вивчення природничих дисциплін i точних наук) http://www.tandfonline.com/toc/hlns20/current $\epsilon$ мультидисциплінарним форумом для презентації досліджень у галузі освіти. Заохочуються публікації статей, у яких представлені нові шляхи розуміння освіти як такої та індивідуального й суспільного розуміння важливості впливу освіти на життя. Журнал публікує дослідницькі статті, які поглиблять розуміння ролі освіти в ситуаціях реального життя, зокрема статті, присвячені питанням ролі інноваційних технологій у забезпеченні глибокого й тривалого навчання. Журнал заохочує статті, що відображають залучення й вдумливу участь у навчальній діяльності, презентують нові методики, що дозволяють ретельніше дослідити процес навчання в реальних ситуаціях.

Журнал Educational Researcher (Освітянин-дослідник) http://journals.sagepub.com/homeledr публікує наукові статті, які мають загальне значення для освітянського дослідницького суспільства й покривають широкий спектр педагогічних і споріднених дисциплін. Журнал має за мету зробити загально 
доступними значущі програмні дослідження і важливі нові отримані дані з широкого спектру педагогічної проблематики. Журнал заохочує написання трьох типів наукових публікацій: нариси, огляди/есе, резюме, які, за необхідності, можна доповнювати технічними коментарями. Також публікуються статті-коментарі до різноманітних форумів, листів, книжок з освітніх питань.

Міжнародний мультидисциплінарний рецензований журнал Learning and Instruction (Вивчення та навчання) https://www.journals.elsevier.com/learning-andinstruction/ забезпечує платформу для публікацій результатів наукових досліджень у сферах вивчення, розвитку, навчання та викладання. Журнал заохочує оригінальні емпіричні дослідження. Статті можуть презентувати широке розмаїття теоретичних перспектив і методологічних підходів. Матеріали можуть стосуватися різних вікових категорій - від немовлят до дорослих, а також широкого спектру дослідницьких засобів - від лабораторних досліджень до польових практик. Найважливішим критерієм релевантності матеріалу $є$ значущість вкладу в справу дослідження особливостей вивчення і навчання.

Міжнародний журнал Educational Research Review (Огляд педагогічних досліджень) https://www.journals.elsevier.com/educational-research-review/ розрахований на окремих дослідників і різні агенції, що зацікавлені в огляді останніх досліджень у галузі освіти і викладання на будь-якому рівні. Журнал публікує мета-аналітичні огляди, наративні огляди, доказові синтези. До друку приймаються:

- дослідницькі огляди (огляди, спрямовані на порівняльне дослідження споріднених або співвідносних питань);

- теоретичні огляди (огляди, спроможні критично описати еволюцію теорій, а також шляхи їх розуміння в різних контекстах);

- методологічні огляди (огляди, присвячені методам i методикам, які використовуються в педагогіці);

- тематичні огляди (огляди, що базуються на описі визначеного ареалу наукової літератури, або на окремо визначених освітніх підходах і моделях навчання);

- теоретичні доробки (наукові праці найвищого гатунку, які стосуються публікацій, порівнянь, аналізів прикладних методів і моделей, що використовуються в освітньому процесі);

- дослідницькі критики (огляди вибраних освітянських тем, що віддзеркалюють певну імплікацію в галузі освіти);

- форумні записи (більш стислі статті, що презентують нові ідеї, або є реакцією на раніше опубліковані матеріали, що стимулюють дебати);

- інструкційні методи (доповіді про інструкційні методи, коли використання адекватного контролю демонструє достовірність результатів проведених досліджень).

\section{4. ВИСНОВКИ ТА ПЕРСПЕКТИВИ ПОДАЛЬШИХ ДОСЛІДЖЕНЬ}

Отже, як показав нетнографічний аналіз провідних науково-педагогічних видань світу, пріоритетність тем публікацій у різних журналах з бази Scopus - різна. Одні журнали надають перевагу теоретико-методологічним оглядам, інші - конкретним емпіричним результатам. У деяких виданнях представлені статті як теоретичного, так i практичного плану.

До напрямів подальших досліджень відносимо вивчення цінової політики журналів, тематичного спектру публікацій провідних країн Європи і країн пострадянського простору, а також вимог до змісту й оформлення публікацій у цих журналах. Також потребує аналогічного дослідження тематичне покриття видань у базі Web of Science, зокрема, iii українського сегменту. 


\title{
СПИСОК ВИКОРИСТАНИХ ДЖЕРЕЛ
}

[1] А. Коломієць, "Механізми самооцінювання наукової активності та наукової продуктивності викладачів вищої школи", Наукові записки Вінницького державного педагогічного університету імені Михайла Кочүюбинського. Серія: Педагогіка і психологія, № 47, с. 14-18, 2016.

[2] А. Мазаракі, Н. Притульська, та С. Мельниченко, "Інтеграція вітчизняної науки до світової через наукометричні бази даних", Вісник КНТЕУ, № 6, с. 5-11, 2011.

[3] V. R. Kozinetz, Netnography: Doing Ethnographic Research Online. L.: Sage, 2010.

[4] В. Биков, та М. Лещенко, "Цифрова гуманістична педагогіка відкритої освіти", Проблеми та перспективи формування національної гуманітарно-технічної еліти, № 45, с. 17-46, 2016.

[5] М. Лещенко, "Зарубіжні педагогічні підходи до наукових досліджень інтернет-мереж", на Всеукр. наук.-практ. сем. Педагогічна компаративістика - 2015: трансформації в освіті зарубіжжя та украӥнський контекст, Київ, 2015, с. 253-257.

[6] О. Сагинова, та К. Афанасиади, "Жалобы онлайн: нетнографические исследования неудовлетворенных потребителей", Маркетинг и маркетинговые исследования, № 6, с. 436-441, 2011.

[7] В. Биков, О. Спірін, та Н. Сороко, "Електронні бібліометричні системи як засіб інформаційноаналітичної підтримки науково-педагогічних досліджень", Інформаційно-комунікаційні технології в сучасній освіті: досвід, проблеми, перспективи, № 1, с. 91-100, 2015.

Матеріал надійчов до редакиї 11.05.2017 p.

\section{НЕТНОГРАФИЧЕСКИЙ АНАЛИЗ ТЕМАТИЧЕСКОГО СПЕКТРА ПЕДАГОГИЧЕСКИХ ИССЛЕДОВАНИЙ В ИЗДАНИЯХ ИЗ НАУКОМЕТРИЧЕСКОЙ БАЗЫ SCOPUS}

\author{
Коломиец Алла Николаевна \\ доктор педагогических наук, профессор, проректор по научной работе \\ Винницкий государственный педагогический университет имени Михаила Коцюбинского, \\ г. Винница, Украина \\ ORCID ID 0000-0003-0536-0147 \\ alla_kolomiec@mail.ru
}

\section{Громов Евгений Владимирович}

кандидат педагогических наук, начальник аналитическо-организационного отдела,

Винницкий государственный педагогический университет имени Михаила Коцюбинского,

г. Винница, Украина

ORCID ID 0000-0002-0234-606X

vdpu2004@i.ua

\begin{abstract}
Аннотация. В статье осуществлён нетнографический анализ сайтов зарубежных педагогических изданий, входящих в наукометрическую базу данных Scopus, дана оценка приоритетным направлениям педагогических исследований в наиболее цитируемых журналах мира. Проанализировано тематическое покрытие первых трёхсот педагогических изданий из рейтингового списка, представленного на Интернет-платформе Scimago Journal \& Country Rank. Проведено сравнение показателей цитируемости зарубежных педагогических журналов c соответствующими показателями изданий технической, естественнонаучной, правовой и политической направленности. Авторами была опровергнута распространённая ошибочная точка зрения о недостаточной представленности или вообще отсутствии педагогических изданий в базе данных Scopus. Выяснено, что среди педагогических изданий, индексируемых в Scopus, наибольшее число посвящено проблематике общего образования и воспитания; педагогической психологии и социологии; организации педагогических исследований, педагогической статистике.
\end{abstract}

Ключевые слова: нетнографический анализ; сравнение; педагогические издания; тематика исследований; наукометрическая база Scopus; Интернет-платформа Scimago Journal \& Country Rank; приоритеты педагогической науки. 


\title{
NETNOGRAPHIC ANALYSIS OF PEDAGOGICAL INVESTIGATIONS SUBJECT SPECTRUM OF PERIODICAL JOURNALS WHICH ARE INDEXED IN SCOPUS SCIENTOMETRIC DATABASE
}

\author{
Alla M. Kolomiets \\ Dr.hab. in Pedagogics, Professor, Vice-rector for Scientific Work, \\ Vinnytsia State Pedagogical University named after Mykhailo Kotsiubynsky, Vinnytsia, Ukraine \\ ORCID ID 0000-0003-0536-0147 \\ alla_kolomiec@mail.ru \\ Yevhen V. Gromov \\ PhD in Pedagogics, Lecturer, Head of Research and Development Department, \\ Vinnytsia State Pedagogical University named after Mykhailo Kotsiubynsky, Vinnytsia, Ukraine \\ ORCID ID 0000-0002-0234-606X \\ vdpu2004@i.ua
}

\begin{abstract}
Netnographic analysis of international pedagogical periodical journals which are indexed in Scopus scientometric database has been realized in the article. The authors gave appraisal of pedagogical investigations' priority directions which are published in the most quoted world's journals. Subject coverage of the Top-300 pedagogical periodical journals from the ranklist presented by Scimago Journal \& Country Rank Internet-platform has been also analyzed. Comparison between pedagogical journals' quotation-indexes and corresponding indexes of technical, natural-scientific, legislative and political subject issues has been also completed. The authors succeeded in refuting the widely-spread but mistaken opinion that pedagogical issues are insufficiently presented or even absent in Scopus database. It has also been found out that the majority of pedagogical periodical journals which are indexed in Scopus deal with problems of general education and upbringing; pedagogical psychology and sociology; organizing of pedagogical investigations and pedagogical statistics.
\end{abstract}

Keywords: netnographic analysis; comparison; pedagogical issue; investigation subject; Scopus scientometric database; Scimago Journal \& Country Rank Internet-platform; pedagogical science priorities.

\section{REFERENCES (TRANSLATED AND TRANSLITERATED)}

[1] A. Kolomiyets, "Mechanisms of self-assessment of scientific activity and scientific productivity of higher school teachers", Scientific Bulletin of Vinnytsia State Pedagogical University named after Mykhaylo Kotsyubynsky. Series: Pedagogics and Psychology, № 47, p. 14-18, 2016 (in Ukrainian).

[2] A. Mazaraki, N. Prytulska, and S. Melnychenko, "Integration of National Science into the World's Scientific Scope via Scientometric Databases", Scientific Bulletin of KNTEU, № 6, p. 5-11, 2011 (in Ukrainian).

[3] V.R. Kozinetz, Netnography: Doing Ethnographic Research Online. L.: Sage, 2010 (in English).

[4] V. Bykov, and M. Leshchenko, "Digital humanistic pedagogy of open education", Problems and perspectives of formation of national humanity-technical elite , № 45, p. 17-46, 2016 (in Ukrainian).

[5] M. Leshchenko, "Foreign pedagogical approaches to scientific investigations of The Internet networks", in Ukrain. scien.-pract. sem. Pedagogical Comparative Studies - 2015: transformations in foreign education and the Ukrainian context, Kyiv, 2015, p. 253-257 (in Ukrainian).

[6] O. Sahynova, and K. Afanasyady, "On-line complains: netnographic investigations of unsatisfied consumers", Marketing and Market Investigations, № 6, p. 436-441, 2011 (in Ukrainian).

[7] V. Bykov, O. Spirin, and N. Soroko, "Electronic bibliometric systems as a means of informational and analytical support of scientific pedagogical investigations", Informational-communicational technologies in modern education: experience, problems, perspectives, № 1, p. 91-100, 2015 (in Ukrainian).

\section{$(\mathrm{cc}) \mathrm{Br}-\mathrm{NC}-\mathrm{SA}$}

This work is licensed under Creative Commons Attribution-NonCommercial-ShareAlike 4.0 International License. 